\title{
Studies on a Bactericidal Substance Produced by Group A Streptococci
}

\author{
By L. F. WOLFF AND J. L. DUNCAN \\ Department of Microbiology, Northwestern University Dental and \\ Medical Schools, Chicago, Illinois 6061 I, U.S.A.
}

(Received 20 September 1973)

\begin{abstract}
SUMMARY
During bacteriophage studies of group A streptococci, some strains produced an inhibitory substance active against other group A strains. The inhibitory material was not found in broth cultures and could only be extracted from cultures grown in semi-solid agar; its activity was assayed by the inhibition of growth and killing of a sensitive group A strain, 12203 . Viable counts showed that $2 \mathrm{~h}$ exposure to the factor at $37{ }^{\circ} \mathrm{C}$ produced greater than $90 \%$ inhibition and more than $60 \%$ killing of the treated culture. Turbidimetric measurements indicated no gross lysis of the sensitive culture and a dose-response curve demonstrated that approximately two bactericidal factor molecules were sufficient to inactivate a colony-forming unit of strain 12203 . The inhibitory factor was of low molecular weight as judged by its diffusibility; it was concentrated by lyophilization and partially purified by gel filtration on G-Io Sephadex. The factor was resistant to proteolytic enzymes, nucleases and lipase as well as reducing and oxidizing conditions. Activity was lost at $60^{\circ} \mathrm{C}$, but the factor was stable at $-70^{\circ} \mathrm{C}$. The bactericidal substance was stable within the $\mathrm{pH}$ range 2 to $\mathrm{I} 2$. These properties, as well as the wide range of activity of the bactericidal factor on several Gram-positive and -negative organisms, suggest that it is an inhibitory substance other than a bacteriocin.
\end{abstract}

\section{INTRODUCTION}

Streptococci produce a wide variety of extracellular products, some of which affect mammalian cells and tissues. There have been occasional reports of antibacterial substances and bacteriocins produced by streptococci, but usually these products have not been isolated and characterized. Sherwood, Russell, Jay \& Bowman (1949) investigated an antibiotic-like substance produced by beta haemolytic streptococci which was active against other beta haemolytic streptococci but only displayed inhibitory activity on agar or gelatin plates. Kuttner (1966) observed that certain strains of group A streptococci produced a zone of inhibition when spotted on an agar plate containing a lawn of other streptococcal strains; the inhibitory substances were produced more frequently by nephritogenic types than by other serologic types of group A streptococci. Although Kuttner assumed that the antibacterial activity was due to a bacteriocin, she was unable to separate the inhibitory substance from living bacteria. Overturf \& Mortimer (1970) examined the same phenomenon in group A streptococci but concluded that there was no correlation between 'bacteriocin' production and the ability to produce acute glomerulonephritis. They did note, however, that nephritogenic strains tended to produce larger and clearer zones of inhibition.

Schlegel \& Slade (1972; I973) described a bacteriocin (streptocin) produced maximally by the Challis strain of Streptococcus sanquis (group $\mathrm{H}$ ) during exponential growth in broth cultures. It was sensitive to trypsin, phospholipase $\mathrm{C}$ and alkaline phosphatase, indicating 
that it may be a complex molecule (protein and lipid) containing phosphate groups essential for activity. This streptococcal bacteriocin was partially purified by gel filtration on Sephadex G-IOO and appeared to exist in equilibrium between two molecular weight forms (28000 and I 10000). The streptocin was bactericidal and active against another group $\mathrm{H}$ strain as well as group A streptococci and a strain of Bacillus subtilis but not against Gram-negative bacteria (personal communication).

Kelstrup \& Gibbons (1969) observed inhibitory substances produced by streptococci indigenous to the oral cavity. They used the term bacteriocin to describe this antibacterial substance but could only demonstrate inhibitory material in bacteria-free filtrates when low concentrations of agar or starch were incorporated into the broth medium. Kramer \& Brandis (1972) detected a low molecular weight bacteriocin (10000) from Streptococcus agalactiae strain 73 produced in stationary phase broth cultures. Brock, Preacher \& Pierson (1963) found that bacteriocins produced by group D streptococci represented five different types depending on their spectrum of activity and physical characteristics but they, too, could only detect inhibitory activity on plates and not in bacteria-free broth filtrates.

During bacteriophage studies of group A streptococci, we observed zones of inhibition in bacterial lawns around certain strains growing on agar plates. This phenomenon appears identical to that described by Sherwood et al. (1949), Kuttner (1966) and Overturf \& Mortimer (1970). We have isolated and partially purified a bactericidal factor from three beta haemolytic strains. The wide range of activity of these bactericidal substances as well as their extremely low molecular weight suggest that they are microbial inhibitors other than bacteriocins.

\section{METHODS}

Bacterial strains. Streptococcal organisms used for the production of bactericidal factor included strain DS-I9I2-65, a beta haemolytic, atypical group G type 12 organism originally isolated from a patient with acute glomerulonephritis. This strain is one of only three documented group $\mathrm{G}$ streptococci which possess the group A type I2 M protein (Maxted \& Potter, 1967). Two beta haemolytic group A strains, s23g lacking the M antigen and initially isolated from a patient with lobar pneumonia (Dochez, Avery \& Lancefield, 1919), and s7 6 (type 6) obtained from a patient with an upper respiratory infection, were also used to produce bactericidal factor. The sensitive organism used throughout this investigation was the group A type 6 strain I2203 (NCTC strain 8709). These organisms, as well as all other group A strains used in this study, were obtained from the laboratory of Dr H. Slade, Northwestern University Dental and Medical School.

Media. The standard medium used for culture growth and maintenance (BHYT) consisted of brain heart infusion broth (Difco) to which was added $0.2 \%$ yeast extract (Difco), 0.0 I mg L-tryptophan $/ \mathrm{ml}$ and $\mathrm{CaCl}_{2}\left(\mathrm{IO}^{-4} \mathrm{M}\right)$. For preparation of plates, agar was added to a final concentration of $1.5 \%(w / w)$. Soft agar used in the production of the bactericidal factor consisted of $2 \%$ proteose peptone No. 3 (Difco) and $0.7 \%$ agar. All stock cultures were maintained on BHYT agar slants at $4{ }^{\circ} \mathrm{C}$.

Bactericidal factor production. The bactericidal factor was extracted from semi-solid medium in which the producer had been grown. An overnight culture of a producer strain was inoculated into fresh BHYT broth and grown to an extinction of 0.6 (the $E_{540}$ of bacterial suspensions was read in a Coleman Model 44 spectrophotometer). An inoculum $(0.5 \mathrm{ml})$ of this culture was added to $3 \mathrm{ml}$ of proteose peptone $(2 \%, \mathrm{w} / \mathrm{w})$ soft agar and then layered over freshly prepared BHYT agar plates. After the soft agar had solidified, I $\mathrm{ml}$ of the producer culture was added to the surface and the plates were incubated at $37^{\circ} \mathrm{C}$ for $\mathrm{I} 6 \mathrm{~h}$. 
The soft agar layer was then scraped off with a glass rod and centrifuged at $10000 \mathrm{~g}$ for $20 \mathrm{~min}$. The supernatant containing the active bactericidal principle was sterilized by filtration through a membrane filter $\left(0.45 \mu \mathrm{m}\right.$ HA, Millipore Corp.) and stored at $-70^{\circ} \mathrm{C}$. Soft agar which had not been inoculated was prepared in a similar manner and served as the control.

Assay of bactericidal factor. Two types of biological assay were used to measure bactericidal factor activity.

(i) Plate assay. The procedure was a modification of that described by Kuttner (I966). The producer strain, grown to an $E_{540}$ of $0 \cdot 6$, was spotted on a BHYT agar plate and incubated for $18 \mathrm{~h}$ at $37^{\circ} \mathrm{C}$. The strain to be tested for sensitivity was grown to an $E_{540}$ of 0.3 and diluted $\mathrm{I}: 400$ in BHYT. One $\mathrm{ml}$ of this dilution was pipetted onto the surface of a plate containing a spot of producer. After the plates were rotated to obtain a uniform bacterial lawn, the excess fluid was removed with a pipette. After further incubation, a clear zone of inhibition around the producer strain was interpreted as a positive test, indicating susceptibility of the indicator strain to bactericidal factor. It was also possible to demonstrate zones of inhibition around most strains when they were spotted on plates just after the addition of the sensitive organism.

(ii) Broth assay. The activity of bactericidal factor was assayed in broth by measuring the inhibition of growth and killing of a sensitive strain. The sensitive strain was grown to an $E_{540}$ of 0.3 in BHYT broth, a $10^{-2}$ dilution made, and an equal volume of bactericidal factor was added. Incubation was carried out at $37^{\circ} \mathrm{C}$ for $2 \mathrm{~h}$ and viable counts determined. The broth filtrate obtained from uninoculated soft agar harvested from plates was used as the control in these experiments. Activity was expressed in two ways: 'Inhibition' is defined as the difference in colony-forming units/ml between control organisms (exposed to uninoculated agar extracts) and organisms exposed to bactericidal factor for $2 \mathrm{~h}$. 'Killing' is defined as the decrease in viable count between $\mathrm{o}$ and $2 \mathrm{~h}$ after exposure to bactericidal factor.

Concentration and purification of bactericidal factor. The bactericidal factor was harvested from soft agar plates and lyophilized. Lyophilized material (I g) was dissolved in $4 \mathrm{ml}$ water adjusted to $\mathrm{pH} 7$, giving a 20-fold concentration of the bactericidal factor. The particulate matter was removed by centrifuging at $10000 \mathrm{~g}$ for Io $\mathrm{min}$ and $2 \mathrm{ml}$ of the supernatant was partially purified by gel filtration on Sephadex G-25 or G-Io (Pharmacia) with bed dimensions of $25 \times 170 \mathrm{~mm}$. Sterile water, $\mathrm{pH} 7$, was used as the eluant. Fractions $(2 \mathrm{ml})$ were collected at $4{ }^{\circ} \mathrm{C}$ and each fraction measured for inhibitory and bactericidal activity by the broth assay as previously described. Protein was determined by the method of Lowry, Rosebrough, Farr \& Randall (195I).

Enzymes and chemicals. Lipase, dithiothreitol, ribonuclease, pronase and alpha amylase were obtained from Sigma and trypsin from Schwarz/Mann Laboratories. For determining the effect of enzymes and dithiothreitol on bactericidal factor activity, the bactericidal factor was incubated for $30 \mathrm{~min}$ at $37^{\circ} \mathrm{C}$ with $100 \mu \mathrm{g}$ enzyme $/ \mathrm{ml}$. The enzyme-treated preparation was then measured for activity by the broth assay.

\section{RESULTS}

\section{Production, assay procedures and range of activity}

The bactericidal substance was first detected in the course of bacteriophage studies of group A streptococci using phage techniques similar to those of Zabriskie (I964). Briefly, lawns of the bacterial strains to be tested were prepared on agar plates, exposed to u.v. light for $20 \mathrm{~s}$, then spotted with about $0.0 \mathrm{I} \mathrm{ml}$ of cultures of other group A strains. After 
Table I. Representative group A strains exhibiting inhibitory activity against other group A strains

\begin{tabular}{|c|c|c|c|c|c|c|c|c|}
\hline \multirow[b]{2}{*}{ Test strain } & \multicolumn{8}{|c|}{ Producer strain } \\
\hline & $\begin{array}{c}17 \mathrm{I} \\
\text { type I }\end{array}$ & $\begin{array}{c}\text { I2205 } \\
\text { type } 27\end{array}$ & $\begin{array}{c}\text { A6s } \\
\text { type } 6\end{array}$ & $\begin{array}{c}\text { s716 } 6 \\
\text { type } 6\end{array}$ & $\begin{array}{c}3465 \\
\text { type I2 }\end{array}$ & s23g* & $\begin{array}{c}\text { T25 } \\
\text { type } 25\end{array}$ & $\begin{array}{c}\text { DS- } \\
\text { I9I2-65† } \\
\text { type I2 }\end{array}$ \\
\hline $\begin{array}{l}3465 \\
\text { type I2 }\end{array}$ & - & - & + & - & - & - & - & + \\
\hline $\begin{array}{r}\text { S43CM39 } \\
\text { type } 6 \\
88\end{array}$ & - & + & + & + & + & + & - & + \\
\hline type 25 & + & + & - & - & + & + & - & + \\
\hline $\begin{array}{l}\text { DS-19I2-65 } \\
\text { type I2 }\end{array}$ & + & + & - & - & + & + & - & + \\
\hline $\begin{array}{l}17 \mathrm{I} \\
\text { type I }\end{array}$ & - & - & - & - & - & - & - & + \\
\hline $\begin{array}{l}12203 \\
\text { type } 6\end{array}$ & + & - & - & + & - & + & + & + \\
\hline
\end{tabular}

+ , Zone of inhibition; - , no zone of inhibition.

* A glossy strain lacking $M$ antigen. The original parent strain, s23, had type 14 protein.

$\dagger$ A group G streptococci with type 12 M protein.

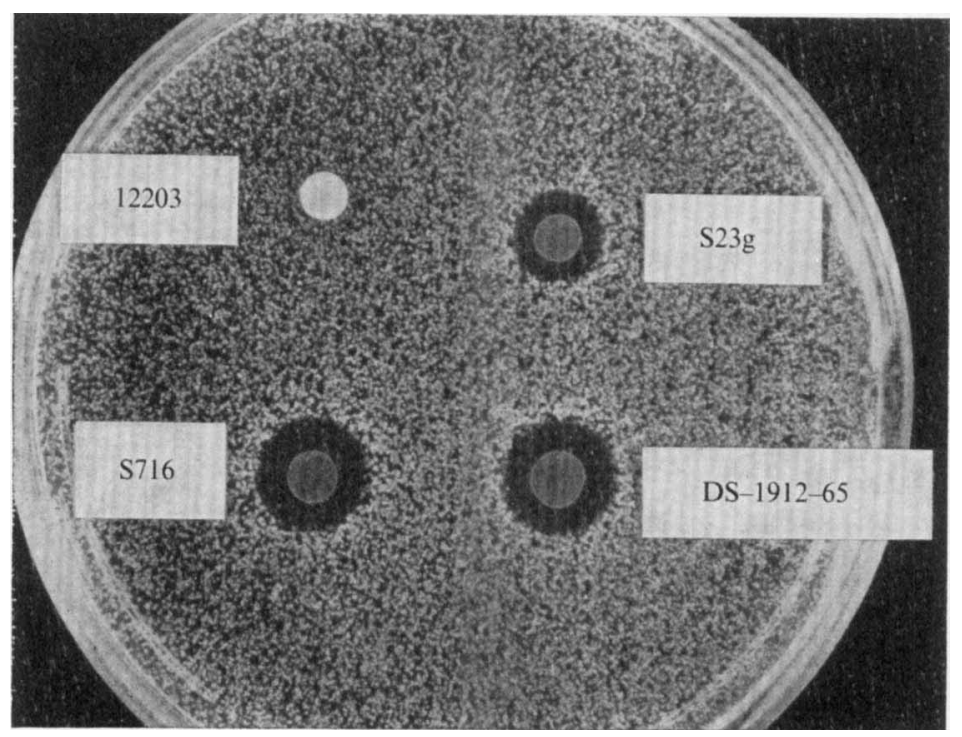

Fig. I. Inhibition produced by strains S7I6, DS-1912-65, S23g and 12203 on a lawn of sensitive organisms.

incubation, many of the discrete spots of growth of the group A strains were surrounded by a well-defined, clear area in which the growth of the lawn was completely inhibited. These initial studies indicated that many group A strains produced an inhibitory substance which diffused into the agar and inhibited the growth of sensitive organisms. Table I shows some of the group A streptococci in which we observed production of or sensitivity to the inhibitory substance. Subsequently, we found that a $I: 400$ dilution of a sensitive strain grown to $E_{540}$ of $0 \cdot 3$, when added as a lawn to an agar plate, produced a suitable background 
Table 2. Effect of medium on the production of bactericidal factor

\begin{tabular}{|c|c|}
\hline Medium* & $\begin{array}{c}\text { Activity } \dagger \\
(\% \text { inhibition of } 12203)\end{array}$ \\
\hline Proteose peptone $(2 \%)$ & 97 \\
\hline Brain heart infusion & 91 \\
\hline \multirow{2}{*}{\multicolumn{2}{|c|}{$\begin{array}{l}\text { Brain heart infusion plus proteose } \\
\text { peptone }(2 \%)\end{array}$}} \\
\hline & 85 \\
\hline Brain heart infusion plus horse serum $(5 \%)$ & 35 \\
\hline \multicolumn{2}{|l|}{ Brain heart infusion plus thioglycollate } \\
\hline Thioglycollate & 0 \\
\hline Todd Hewitt & 0 \\
\hline Trypticase soy & 34 \\
\hline Nutrient & 16 \\
\hline
\end{tabular}

* All media contained $0.7 \%$ agar.

$\dagger$ Activity is expressed as the percentage inhibition of 12203 after $2 \mathrm{~h}$ exposure to each agar extract inoculated with DS-19I2-65, compared with uninoculated control extracts.

for demonstrating zones of inhibition. A typical plate assay is shown in Fig. $I$ in which the zone of inhibition can readily be seen.

Although the inhibitory activity of DS-1912-65 and many other strains could be demonstrated on agar plates it could not be detected in broth filtrates when these strains were grown in liquid media. Several types of broth media were investigated for the production of the inhibitory substance including brain heart infusion (BHI), BHI plus horse serum $(5 \%)$, BHI plus proteose peptone $(2 \%)$, BHI plus thioglycollate medium ( $32 \%)$, trypticase soy, and Todd Hewitt. The inhibitory substance was not detected in broth media incubated over a layer of soft agar, in liquid cultures incubated under anaerobic or highly aerobic conditions, or in an atmosphere of $\mathrm{CO}_{2}$. The possibility that the substance was produced in broth cultures at some critical point in the growth cycle and then rapidly inactivated was examined, but inhibitory activity was not detected at any stage of the growth period.

Although the inhibitory substance could not be detected in broth cultures under a variety of conditions, we were able to isolate it when the producer strain was inoculated into molten $\left(50^{\circ} \mathrm{C}\right)$ soft agar, then poured over a hard agar base and incubated at $37^{\circ} \mathrm{C}$. Table 2 shows the effect of various types of soft agar media on the production of the bactericidal factor by DS-I9I2-65. Highest yields of the bactericidal factor activity were consistently found in proteose peptone ( $2 \%$ ) soft agar cultures; brain heart infusion and BHI plus proteose peptone $(2 \%)$ also gave good yields. Brain heart infusion plus horse serum $(5 \%)$, trypticase soy and nutrient soft agar cultures all gave significantly less activity, while cultures growing in Todd Hewitt or thioglycollate agar produced no detectable inhibitory activity. Soft agar harvested at around $\mathrm{I} 6 \mathrm{~h}$ exhibited maximum bactericidal factor activity. When producer cells were incubated in soft agar for more than $36 \mathrm{~h}$, activity was significantly diminished.

The broth filtrates prepared from soft agar inoculated with either DS-1912-65, S23g or s7 16 consistently produced greater than $90 \%$ inhibition and $60 \%$ killing of the sensitive strain 12203 after $2 \mathrm{~h}$ incubation (Table 3). After $24 \mathrm{~h}$, the killing of 12203 by the DS-I9I 2-65 bactericidal factor was greater than $95 \%$. The killing effect obtained with bactericidal factor prepared from s7 6 and s23g was even greater at $24 \mathrm{~h}$, decreasing the viable count by more than $99 \%$.

Although the bactericidal substance significantly affected the sensitive strain I 2203 in the 
Table 3. The inhibitory and bactericidal activity of bactericidal factor prepared from DS-19I2-65, S7I 6 and S23g

$\begin{array}{lccccc}\begin{array}{c}\text { Bactericidal } \\ \text { factor }\end{array} & \begin{array}{c}\text { Viable count } \\ \text { (zero time) } \\ \times 10^{-5}\end{array} & \begin{array}{c}\text { Viable count } \\ \text { (control) } \\ \times 10^{-6}\end{array} & \begin{array}{c}\text { Viable count } \\ \text { (experimental } \\ \text { I20 min) } \\ \times 10^{-4}\end{array} & \begin{array}{c}\text { Inhibition } \\ \text { of } 12203 \\ (\%)\end{array} & \begin{array}{c}\text { Killing } \\ \text { of } 12203 \\ (\%)\end{array} \\ \text { DS-1912-65 } & 5.85 & 2.55 & 13.5 & 96 & 77 \\ \text { S716 } & 4.65 & 2.60 & 5.90 & 98 & 87 \\ \text { S23 g } & 4.65 & 2.60 & 5.50 & 98 & 88\end{array}$

Bactericidal factor was measured for killing and inhibitory activity on the sensitive strain I 2203 by the broth assay as described in materials and methods. Viable counts are the average of duplicate plates.

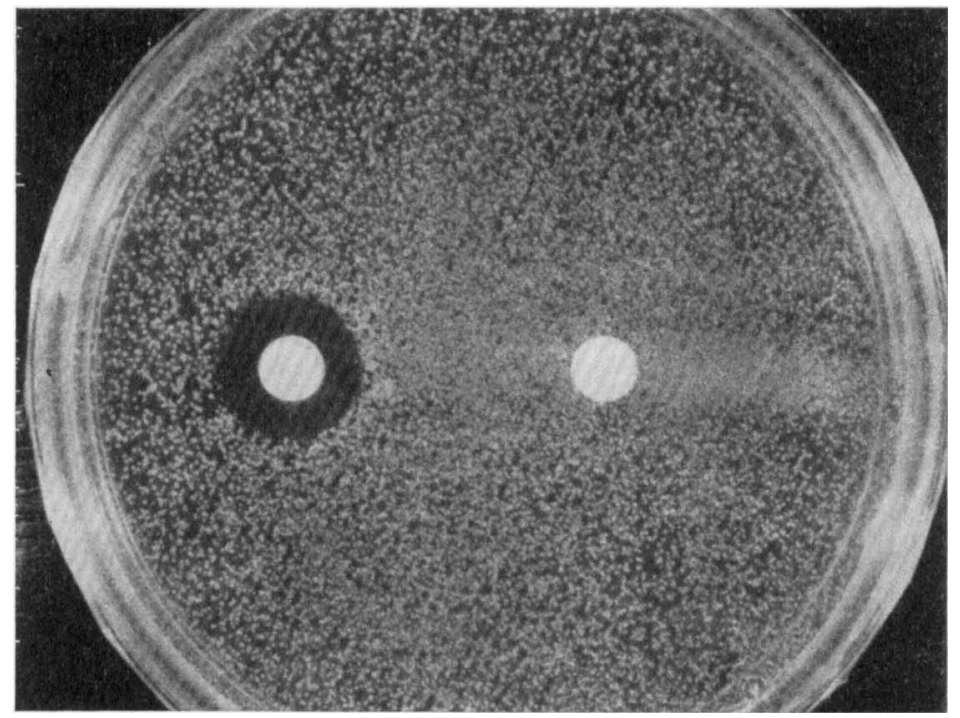

Fig. 2. Inhibition produced on a lawn of 12203 organisms by filter paper discs saturated with bactericidal factor.

broth assay, no inhibition was observed when sterile broth containing inhibitory activity was spotted on a lawn of 1 2203. However, when sterile filter paper discs were soaked in the broth filtrate containing active bactericidal factor and then placed on a lawn of 12203, a significant zone of inhibition was produced (Fig. 2).

Table 4 shows the range of activity of the DS-I9I 2-65 bactericidal factor. The plate assay revealed that 24 out of 28 Streptococcus pyogenes strains were sensitive to this bactericidal factor and all other bacterial species tested were susceptible except a strain of Bacillus subtilis. In general there was good correlation between the size of the inhibition zones observed in the plate assay and the inhibition of growth found in the broth assay. The group A strain 12203 as well as Staphylococcus aureus, Sarcina lutea and Escherichia coli were all very sensitive to the DS-1912-65 bactericidal factor in the plate and broth assays. In addition to its wide range of activity on both Gram-positive and Gram-negative bacteria, the DSI 9I2-65 bactericidal factor also affected cultures of DS-I9I2-65, i.e. it was autoinhibitory. 
Table 4. Range of inhibitory activity of bactericidal factor

\begin{tabular}{|c|c|c|}
\hline Test organism & Plate assay* & $\begin{array}{c}\text { Broth assay } \dagger \\
\text { (\% inhibition) }\end{array}$ \\
\hline \multicolumn{3}{|l|}{ Streptococcus pyogenes } \\
\hline 24 group A strains & + to +++ & Not tested \\
\hline I 2203 & +++ & 96 \\
\hline 5716 & + & 60 \\
\hline $3 \mathrm{gLI} 6 \mathrm{~s}^{\mathrm{r}}$ & ++ & 81 \\
\hline 4 group A strains & - & Not tested \\
\hline Staphylococcus aureus & $++t$ & 98 \\
\hline Sarcina lutea & $++t$ & Not tested \\
\hline Pseudomonas aeruginosa & + & Not tested \\
\hline Escherichia coli & +++ & 96 \\
\hline Proteus vulgaris & ++ & Not tested \\
\hline Streptococcus faecalis & + & Not tested \\
\hline Bacillus subtilis & - & Not tested \\
\hline
\end{tabular}

+ , Zone diameter less than $5 \mathrm{~mm} ;++$, zone between 5 and $15 \mathrm{~mm} ;+++$, zone greater than $15 \mathrm{~mm}$; - , no zone.

* DS-I912-65 Cells were spotted on BHYT again containing a lawn of the test organism. The diameter of the zones of inhibition were measured after $18 \mathrm{~h}$ incubation.

$\dagger$ DS-1912-65 Bactericidal factor was incubated with test organisms for $2 \mathrm{~h}$. Inhibition was calculated as the difference in viable count between treated and control cultures.

\section{Bactericidal factor activity on strain 12203}

The group A strain 12203 was routinely used as the sensitive test organism in the following experiments. Fig. 3 shows the kinetics of bactericidal factor action on 12203. The inhibitory and killing effects of bactericidal factor begin immediately, and after $6 \mathrm{~h}$ greater than $99 \%$ inhibition and well over $95 \%$ killing of the sensitive strain were observed.

To determine whether the effects of the inhibitory substance on sensitive bacteria were reversible, factor was incubated with 12203 suspension for $30 \mathrm{~min}$ at $37^{\circ} \mathrm{C}$. After being washed twice in phosphate buffered saline by centrifugation, the organisms were resuspended to the original volume in BHYT broth, incubated at $37^{\circ} \mathrm{C}$ for $2 \mathrm{~h}$ and viable counts determined. No recovery in viable count occurred as a result of the washing procedure.

Fig. 4 shows the effect of DS-1912-65 bactericidal factor on strain I2203 using a turbidimetric assay. Approximately $5 \times 10^{6}$ colony-forming units $/ \mathrm{ml}$ were exposed to bactericidal factor or control extracts, and changes in the extinction of the cultures were followed. The $E_{540}$ of the culture exposed to the bactericidal factor did not increase during the $4.5 \mathrm{~h}$ incubation period, and in fact showed a slight decrease. A Gram stain examination of organisms inhibited by the bactericidal substance did not reveal any abnormalities in morphology. To determine whether leakage of macromolecules occurred after exposure to the bactericidal substance, sensitive organisms suspended in water were incubated with partially purified bactericidal factor for $4 \mathrm{~h}$ at $37^{\circ} \mathrm{C}$. No leakage of DNA and RNA was detected using the Dische and orcinol reactions, even though about $50 \%$ of the cells were killed as determined by viable counts.

Fig. 5 shows the dose response curve obtained when strain 12203 was exposed to various concentrations of DS-I $1912-65$ bactericidal factor. In this experiment, the factor was concentrated by lyophilization, then diluted in BHYT to the desired concentration. The percentage of organisms killed at each concentration after $2 \mathrm{~h}$ was determined. A shoulder is seen on the curve in this graph and the value obtained by extrapolation back to the ordinate suggests that a minimum of two bactericidal factor molecules may be sufficient to kill a single colonyforming unit of the sensitive strain. 


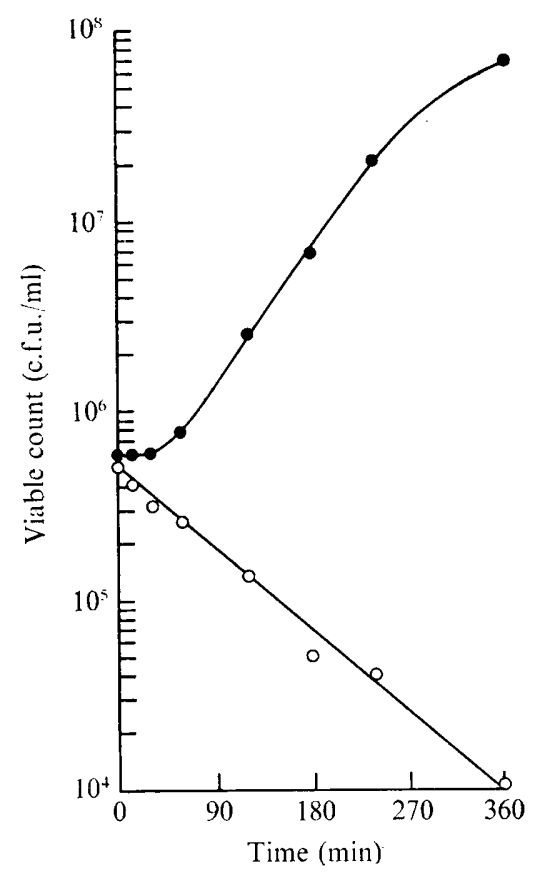

Fig. 3

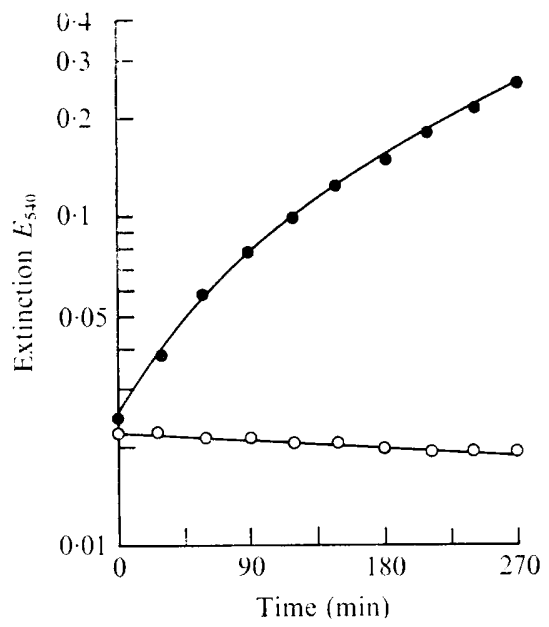

Fig. 4

Fig. 3. Kinetics of DS-I9I 2-65 bactericidal factor action on strain 12203 . O, Bactericidal factor; , control. Viable counts were determined at various times after the addition of the bactericidal factor; c.f.u., colony-forming units.

Fig. 4. Inhibition of growth of strain 12203 by DS-1912-65 bactericidal factor. $O$, Bactericidal factor; control.

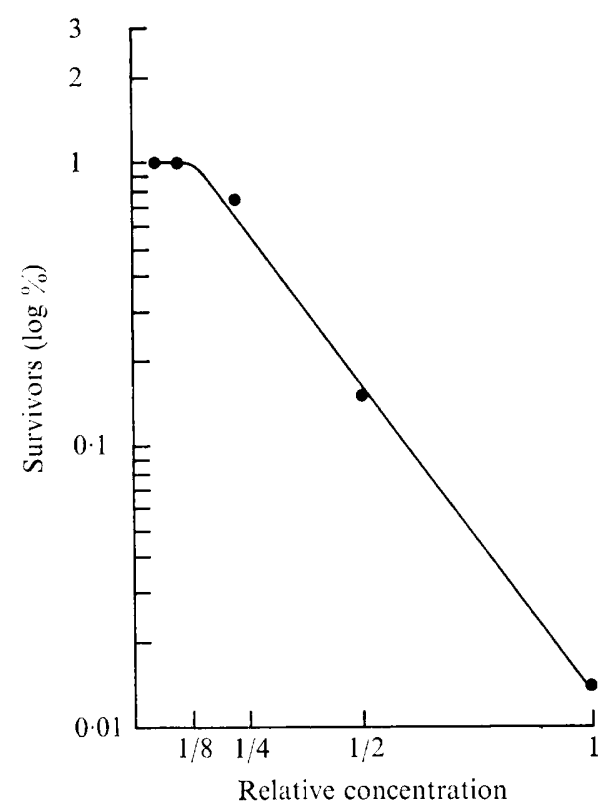

Fig. 5. Effect of different concentrations of DS-1912-65 bactericidal factor on strain 12203 after 2 h. 


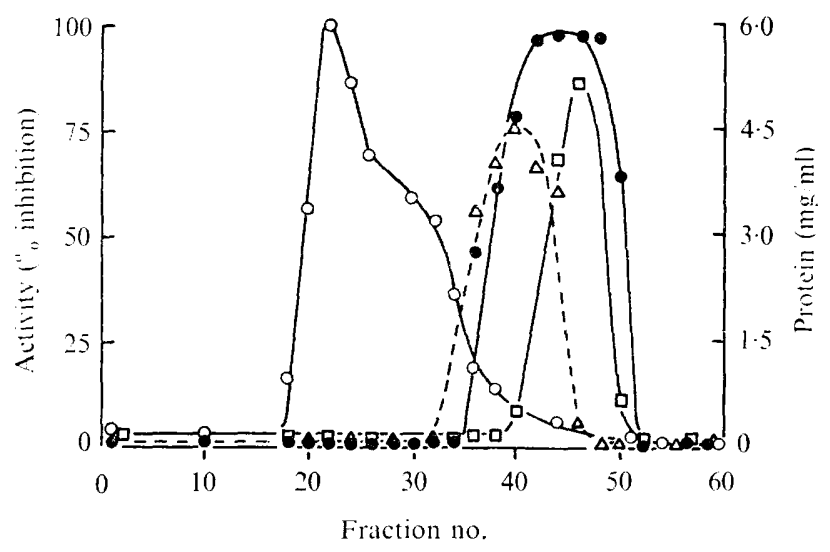

Fig. 6. Gel filtration of bactericidal factor from DS-1912-65, s23g and s716. Two ml of concentrated inhibitory material prepared from each organism were applied to a $25 \times 170 \mathrm{~mm}$ G-10 Sephadex column. Fractions ( $2 \mathrm{ml}$ ) were collected. 0 , DS-1912-65; $\triangle, \mathrm{s} 23 \mathrm{~g} ; \square, \mathrm{s} 716$. Protein $(\mathrm{O})$ determinations were made on the DS-1912-65 run.

\section{Physical characteristics of bactericidal factor}

Studies on the physical characteristics of the inhibitory substance revealed that its molecular weight was sufficiently low to allow it to pass through a dialysis membrane. The factor was resistant to a wide variety of enzymes including pronase, deoxyribonuclease, ribonuclease and lipase. Greater than $50 \%$ activity was lost when bactericidal factor was incubated at $60{ }^{\circ} \mathrm{C}$ for $30 \mathrm{~min}$; however, the factor remained stable for several months at $-70^{\circ} \mathrm{C}$. Oxidizing and reducing conditions had no effect on its activity.

The stability of Ds-1912-65 bactericidal factor at various $\mathrm{pH}$ values was also investigated. Material ( $\mathrm{I} \mathrm{ml}$ ) was exposed for $30 \mathrm{~min}$ at various $\mathrm{pH}$ values in broth using $\mathrm{I} \mathrm{M}-\mathrm{HCl}$ and I $\mathrm{M}-\mathrm{NaOH}$ to adjust the $\mathrm{pH}$. After $30 \mathrm{~min}$ the $\mathrm{pH}$ was readjusted to 7.0 and inhibitory activity assayed by 'broth assay'. Uninoculated soft agar extracts served as the control and were carried through the same $\mathrm{pH}$ changes. Bactericidal factor was stable over a $\mathrm{pH}$ range of 2 to 12 .

\section{Concentration and purification of bactericidal factor}

Bactericidal factor prepared from DS-I9I2-65, S23g and S7I6 was concentrated by lyophilization and added to a G-Io Sephadex column. Maximum bactericidal factor activity prepared from DS-I 9I 2-65 was eluted near fraction 45 with the bulk of the protein coming off much earlier (Fig. 6). Bactericidal factor prepared from \$23g and s7I6 had similar elution profiles on Sephadex G-ro. A glucose marker eluted near the peak of activity suggested that the molecular weight of the factor may be in the neighbourhood of 200 daltons. The specific activity (\% killing/mg protein) of this partially purified material was at least 50 times greater than the crude lyophilized preparation. In addition the total bactericidal activity eluted from Sephadex was about ten times greater than the total amount of activity applied to the column. This suggests that crude preparations may contain an inhibitor which is separated away from the factor during gel filtration. 


\section{DISCUSSION}

In addition to observing zones of inhibition in bacterial lawns on agar plates produced by group A streptococci, we have obtained cell-free broth preparations of a bactericidal factor from semi-solid media. The factor appears to be identical to the inhibitory substances observed by Sherwood et al. (1949), Kuttner (1966) and Overturf \& Mortimer (1970) and our results indicate that these inhibitory substances are not bacteriocins.

In agreement with Kuttner (I966) we were not able to demonstrate inhibitory activity in liquid cultures, but when certain media were supplemented with $0.7 \%$ agar, bactericidal factor production was readily detected. The type of medium used to culture the streptococci also had a profound influence on the production of the bactericidal factor. Maximum bactericidal activity was obtained from semi-solid media (containing proteose peptone or BHI). Bactericidal factor production appeared to be inversely related to growth of the producing organism; proteose peptone, which gave poor growth, gave the highest yields of bactericidal factor activity, whereas media which supported optimal growth yielded less (or no) bactericidal factor production. The finding that purified bactericidal factor has significantly more activity than crude preparations suggests that an inhibitor of bactericidal factor activity may be present in crude extracts, or that some essential metabolite produced in excess during growth, and which would be present in crude extracts, may be antagonizing the activity of the bactericidal substance.

Several explanations could account for the apparent necessity for agar in the production of the bactericidal factor. Kelstrup \& Gibbons (1969) suggested that agar stabilized the low molecular weight inhibitory substance produced by oral streptococci. Another possibility is that the factor is effectively concentrated by the agar whereas in broth media the activity is diluted out to the extent that it is undetectable. An alternative explanation is that a substance antagonistic to bactericidal factor activity may be produced in broth media which is adsorbed or inactivated by the agar in semi-solid media. To test this last possibility, producer cells were cultured in liquid media without agar, and the broth filtrates were added to active bactericidal factor preparations. No decrease in the inhibitory activity of the bactericidal factor was observed. Paper discs soaked in cell-free bactericidal factor preparations gave zones of inhibition in bacterial lawns similar to those observed around spots of producer cells. This finding strongly suggests that the bactericidal factor activity extracted from agar media is identical to the inhibitory activity observed in the plate assay.

A bactericidal factor was produced by most group A strains examined and the inhibitory substance(s) was shown to have a broad spectrum of activity on other strains. However, there appears to be no relationship between serological M-type and production of or sensitivity to bactericidal factor. The antibacterial effects of the bactericidal factor were not limited to other group A strains, but extended to other serological groups of streptococci as well as other Gram-positive and Gram-negative species of bacteria. Only a strain of Bacillus subtilis was not inhibited by the DS-I9I2-65 bactericidal factor. The inhibitory substance did not lyse rabbit erythrocytes, ruling out the possibility that it was streptolysin $\mathrm{S}$, nor did it have any effect on chicken fibroblasts, the only other eucaryotic cell tested.

Viable count determinations and extinction measurements indicated significant inhibition and killing of sensitive cells exposed to the bactericidal substance. A slight decrease in extinction was detected, although gross lysis was not observed. Such a decrease could be due to a leakage of small molecules into the environment as a result of an effect on the membrane. The slight decrease in $E_{540}$ and the finding that DNA and RNA did not escape 
from the organisms suggest that complete membrane dissolution and cell wall rupture do not occur.

The bactericidal factor appears to exert antimicrobial activity by inhibiting the growth of and by killing the sensitive organisms. Fig. 4 suggests that growth in the entire population was inhibited and that this effect occurred immediately after addition of the inhibitory substance. The bacteria were killed at a slower rate (Fig. 3). Moreover, low concentrations of bactericidal factor which appeared to have no lethal effect on the sensitive culture (Fig. 5) produced significant inhibition of growth (not shown). We never observed $100 \% \mathrm{killing}$ of the sensitive strain and there always appeared to be a small resistant population of cells which, upon dilution into fresh medium or on prolonged incubation $(48 \mathrm{~h})$, would grow.

The nature of the ultimate event which leads to the death of the organism has not yet been determined. However, any explanation for the survival curves obtained must recognize that approximately two molecules of the bactericidal factor are required to inactivate a colony-forming unit (Fig. 5). The sensitive strain, 12203, occurs primarily as a diplococcus during the broth assay growth period, and possibly one molecule of bactericidal factor is sufficient to kill a single organism. The finding that the killing effect was not reversible by washing procedures could be explained if the lethal event occurs rather quickly. Alternatively, the bactericidal factor molecule may irreversibly bind to the sensitive organisms and only later during the viable count assay procedure bring about death.

The low molecular weight of bactericidal factor, its autoinhibitory properties and its wide range of antibacterial activity suggest that it is antibiotic rather than a bacteriocin. Diplococcin, an inhibitory substance produced by cultures of certain milk streptococci, was described by Oxford (1944). As well as appearing to be protein in nature and having a low molecular weight, diplococcin had inhibitory activity against strains of Streptococcus cremoris, Strep. lactis and Staphylococcus aureus. Mattick \& Hirsch (1947) and Hurst (1966) studied an antibiotic substance, nisin, from liquid cultures of Strep. lactis which was active against a wide variety of micro-organisms of high molecular weight. Bottone, Allerhand \& Pisano (197I) characterized a low molecular weight antibacterial substance from Strep. faecalis var. zymogenes. They were unable to obtain their inhibitory material in agar-free preparations but found it diffusible, sensitive to heating at $80{ }^{\circ} \mathrm{C}$ for $20 \mathrm{~min}$ and resistant to inactivation by either trypsin or chloroform. Bottone et al. (I97I) and others (Brock et al. 1963; Kuttner, 1966) who observed a diffusible inhibitory substance(s) on agar plates but were unable to separate this antibacterial activity from solid media may have prematurely labelled these inhibitory substances as bacteriocins when in fact they may not meet the criteria described for these large molecular weight molecules (Reeves, 1972). Although the bactericidal factor which we have described fits the criteria for a low molecular weight antibiotic (Gale, Gundliffe, Reynolds, Richmond \& Waring, 1972) the possibility remains that this inhibitory molecule may be further classified as an antimetabolite. The function of this antibacterial substance in the physiology of the producer streptococci and the role it may play in host-parasite relationships remains to be determined. 


\section{REFERENCES}

Bottone, E., Allerhand, J. \& Pisano, M. A. (1971). Characteristics of a bacteriocin derived from Streptococcus faecalis var. zymogenes antagonistic to Diplococcus pneumoniae. Applied Microbiology 22, 200-204.

Brock, T. D., Preacher, B. \& Pierson, D. (1963). Survey of the bacteriocines of enterococci. Journal of Bacteriology 86, 702-707.

Dochez, A. R., Avery, O. T. \& Lancefield, R. C. (I919). Studies on the biology of streptococcus. I. Antigenic relationships between strains of Streptococcus haemolyticus. Journal of Experimental Medicine 3o, $179-213$.

Gale, E. F., Gundliffe, E., Reynolds, P. E., Richmond, M. H. \& Waring, M. J. (1972). The Molecular Basis of Antibiotic Action. New York: John Wiley.

Hurst, A. (1966). Biosynthesis of the antibiotic nisin and other basic peptides by Streptococcus lactis grown in batch culture. Journal of General Microbiology 45, 503-513.

Kelstrup, J. \& GibBons, R. J. (1969). Bacteriocins from human and rodent streptococci. Archives of Oral Biology 14, 25I-258.

KRAMER, J. \& BRANDIS, H. (1972). Charakterisierung eines Streptococcus agalactiae-Bacteriocins. Zentralblatt für Bakteriologie, Parasitenkunde, Infektionskrankheiten und Hygiene (Abteilung I) 219, 290-30I.

KUTTNER, A. G. (1966). Production of group A streptococcal bacteriocines with special reference to nephritogenic types. Journal of Experimental Medicine 124, 279-29r.

Lowry, O. H., Rosebrough, N. J., FARR, A. L. \& Randall, R. J. (195I). Protein measurement with the Folin phenol reagent. Journal of Biological Chemistry 193, 265-275.

MatTick, A. T. R. \& HiRSCH, A. (1947). Further observations on an inhibitory substance (nisin) from lactic streptococci. Lancet 2, 5-8.

MAXTED, W. R. \& PotTeR, E. V. (1967). The presence of type 12 M-protein antigen in group G streptococci. Journal of General Microbiology 49, I19-I 25.

OVERTURF, G. D. \& Mortimer, E. A. (1970). Studies of the relationship between the production of bacteriocines by group A streptococci and acute glomerulonephritis. Journal of Experimental Medicine 132, 694-70I.

OXFoRD, A. E. (1944). Diplococcin, an antibacterial protein elaborated by certain milk streptococci. Journal of Biochemistry 38, 178-182.

REEVES, P. (1972). The Bacteriocins. New York: Springer-Verlag.

SCHLEGEL, R. \& SLADE, H. D. (1972). Bacteriocin production by transformable group H streptococci. Journal of Bacteriology II2, 824-829.

Schlegel, R. \& Slade, H. D. (1973). Properties of a Streptococcus sanquis (group H) bacteriocin and its separation from the competence factor of transformation. Journal of Bacteriology $\mathbf{I I 5}_{5}, 655-66 \mathrm{I}$.

Sherwood, N. P., Russel, B. E., JAY, A. R. \& Bowman, K. (I949). Studies on streptococci. III. New antibiotic substances produced by beta hemolytic streptococci. Journal of Infectious Disease 84, 88-91.

ZABRISKIE, J. B. (1964). The role of temperate bacteriophage in the production of erythrogenic toxin by group A streptococci. Journal of Experimental Medicine 119, 76I-779. 